\title{
Effects of Reconstituted Collagen Matrix on Fates of Mouse Embryonic Stem Cells Before and After Induction for Chondrogenic Differentiation
}

\author{
Chiu W. Yeung, Ph.D., Kathryn Cheah, Ph.D., ${ }^{2}$ Danny Chan, Ph.D., ${ }^{2}$ and Barbara P. Chan, Ph.D. ${ }^{1}$
}

Embryonic stem (ES) cells are pluripotent cells with great potential in regenerative medicine. However, controlling their differentiation toward homogeneous lineages is challenging. In this study, we aim to investigate the effects of reconstituted 3D collagen matrix on the fates of mouse ES ( $\mathrm{mES}$ ) cells before and after induction for chondrogenic differentiation. Specifically, mES cells were encapsulated and cultured in 3D collagen microspheres and exposed to induction signals at different time points. Growth characteristics and differentiation status of $\mathrm{mES}$ cells were then evaluated. Collagen microspheres provided a suitable microenvironment supporting mES cell growth and maintaining their undifferentiated status for certain period of time. At later time points, the proportion of undifferentiated $\mathrm{mES}$ cells gradually decreased, accompanied by increasing proportions of mesenchymal progenitor cells. This suggests the inductive role of collagen matrix in differentiating mES cells toward mesenchymal lineages. Moreover, a lower initial collagen monomer concentration facilitated the differentiation of mES cells into chondrogenic lineages, while induction at a later time point associated with a more advanced stage of chondrogenic differentiation. This indicates that both the initial collagen concentration and the time to induce differentiation significantly affected the fates of mES cells. This study contributes to future development of ES cell-based therapies.

\section{Introduction}

E MBRYONIC STEM (ES) CELLS are pluripotent cells derived from the inner cell mass of blastocysts and are capable of self-renewal. ${ }^{1-3}$ ES cells have great potential in tissue engineering and regenerative medicine since they can differentiate into multiple cell types. ${ }^{1,4}$ Nevertheless, one major hurdle in using ES cells as the cell source for tissue engineering and regenerative medicine is their tendency to spontaneously differentiate toward multiple lineages. As a result, it is important to define the culture conditions and other microenvironment for maintenance of the undifferentiated status of ES cells before devising specific differentiation protocols. Leukemia inhibitory factor (LIF), together with the feeder layer support from mitotically inactivated mouse embryonic fibroblast, is commonly used to maintain the ES cells in an undifferentiated status, ${ }^{5}$ which is usually marked by the expression of Oct3/4, SSEA-1, and Nanog. ${ }^{6-9}$

To use ES cells for tissue engineering and regenerative medicine, it is necessary to differentiate ES cells toward a specific lineage. In reality, ES cells spontaneously differentiate into cells of all three germ layers, ${ }^{10}$ usually via the formation of embryoid body (EB), which is an aggregate of ES cells similar to the early postimplantation embryo with characteristic morphogenic processes such as cavitation. ${ }^{1,4,11-14}$ Embryoid bodies are usually generated by suspension culture $^{10,15}$ hanging drops, ${ }^{10,11,16}$ or forced aggregation ${ }^{17,18}$ in the absence of LIF. It is very difficult to obtain sufficient cells of a single lineage, ${ }^{19}$ as EBs usually contain heterogeneous and asynchronous cell populations. ${ }^{20}$ As a result, one has to use specialized techniques to isolate the small proportion of cells of interests from the EBs for further expansion and subsequent differentiation. These techniques include microdissection from plated EBs for cells such as chondrocytes ${ }^{16,21-23}$ and beating cardiomyocytes, ${ }^{24}$ and flow cytometry-based sorting from dissociated EB cells for mesenchymal progenitor cells (MPCs). ${ }^{25}$ Alternative methods include direct application of chondrogenic differentiation medium to $\mathrm{EBs}^{26,27}$ transfection of ES cells with cell-specific differentiationinductive genes such as Osterix for osteoblasts, ${ }^{28}$ and coculture of ES cells with limb bud progenitor cells for chondrocytes. ${ }^{29}$ Nevertheless, one of the biggest challenges in this field is to

\footnotetext{
${ }^{1}$ Medical Engineering Program, Department of Mechanical Engineering; ${ }^{2}$ Department of Biochemistry, Li Ka Shing Faculty of Medicine, The University of Hong Kong, Hong Kong Special Administrative Region, China.

Part of this work has been presented at the 5th International Society for Stem Cell Research Annual Meeting in Cairns, Australia, in June 2007.
} 
differentiate ES cells into single lineages homogenously. Otherwise, clinical application would not be feasible.

In cartilage tissue engineering, inductive signals for chondrogenic differentiation of ES cells are those from embryonic cartilage development. ${ }^{30-32}$ These cell-cell interaction signals are soluble biological factors such as transforming growth factor beta, ${ }^{21,30,33,34}$ bone morphogenic proteins, ${ }^{33,35,36}$ and fibroblast growth factor. ${ }^{31}$ These signals can also be cellmatrix interaction factors including cell adhesion molecules such as $\mathrm{N}$-cadherin ${ }^{37,38}$ and neural cell adhesion molecules, ${ }^{39}$ and extracellular matrix molecules such as fibronectin, proteoglycans, and collagen. ${ }^{30}$ However, supplementing soluble biological signals to the culture medium of stem cells is the most commonly used approach to induce chondrogenic differentiation and cartilage formation, while the roles of other types of inductive signals are rarely explored.

Owing to the advancement of biomaterial research in recent years, culturing ES cells in 3D biocompatible materials becomes possible. The major advantages of $3 \mathrm{D}$ cultures of $\mathrm{ES}$ cells in biomaterials are (i) a greater expansion capacity, ${ }^{40-42}$ although spontaneous differentiation is still substantial, and (ii) the possibility to engineer the specific 3D microenvironment or niche such as the types of matrix ${ }^{11,43,44}$ and the physical properties of matrix ${ }^{18,45,46}$ facilitating ES cell differentiation toward particular lineages. ${ }^{11,26,43} \mathrm{~A}$ wide range of biomaterials have been used for 3D culture systems of ES cells, for examples, poly-L-lactic acid, ${ }^{18}$ polyethylene terephthalate, ${ }^{43,47}$ collagen, ${ }^{45}$ alginate, ${ }^{46}$ fibrin, ${ }^{44}$ Matrigel, ${ }^{43}$ chitosan, ${ }^{42}$ and polyethylene glycol. ${ }^{26,44}$ Collagen is the most abundant extracellular matrix composition in human tissues. It is a naturally occurring biomaterial with excellent biocompatibility, negligible immunogenicity, specific interaction with growth factors and cell adhesion molecules, and biodegradability. ${ }^{48-50}$ Recently, we have developed a collagen microencapsulation method to entrap living cells in collagen microspheres made of reconstituted nanofibrous meshwork. ${ }^{25}$ It has been demonstrated that this biomimetic collagen meshwork provides a biomimetic microenvironment to support proliferation of mesenchymal stem cells (MSCs) without compromising their regeneration potential ${ }^{51}$ and to facilitate their chondrogenic differentiation. $^{52}$

Our ultimate goal is to develop stem cell-based therapies for cartilage tissue engineering. In this study, we aim to investigate the effects of reconstituted collagen matrix meshwork on the fates of mouse ES (mES) cells before and after induction for chondrogenic differentiation. Specifically, we encapsulated and cultured the mES cells in collagen microspheres with different initial collagen monomer concentrations and evaluated their growth characteristics and differentiation status. We also supplemented chemical induction signals for chondrogenic differentiation to the encapsulated mES cells at different time points and evaluated the outcomes of chondrogenic differentiation via a series of cartilage-specific markers.

\section{Materials and Methods}

\section{Cell culture}

mES cells (R1) were kindly provided by Prof. Andras Nagy (Samuel Lunenfeld Research Institute, Toronto, Canada) ${ }^{53}$ and were initially grown on a mitotically inactive MEF feeder layer at $37^{\circ} \mathrm{C}$ in a $5 \% \mathrm{CO}_{2}$ incubator in ES growth medium, defined as Dulbecco's modified Eagle's medium (DMEM) with high glucose (Gibco, Grand Island, NY), $0.5 \mathrm{mM}$ penicillin and streptomycin (Gibco), $2 \mathrm{mM}$ L-glutamine (Gibco), $1 \mathrm{mM}$ nonessential amino acid (Gibco), $1 \mathrm{mM}$ sodium pyruvate (Gibco), 20\% ES cell-qualified fetal bovine serum (Gibco), $100 \mu \mathrm{M} \beta$-mercaptophenol (Sigma, St. Louis, MO), and $10^{3}$ units/mL LIF (Chemicon International, Temecula, CA). The ES cell growth medium was changed daily. Cells at subconfluence were detached by $0.05 \%$ trypsin/25 mmol EDTA (Gibco) for $5 \mathrm{~min}$ and subcultured on $0.1 \%$ gelatin-coated culture plate to maintain a feeder layerfree culture before microencapsulation for at most three passages.

\section{Microencapsulation of mES cells}

mES cells were microencapsulated as previously described. ${ }^{51}$ In brief, rat tail type I collagen (Becton Dickenson Biosciences, Bedford, MA) was neutralized by $0.1 \mathrm{~N} \mathrm{NaOH}$ and diluted into final concentrations of 0.5 and $2.0 \mathrm{mg} / \mathrm{mL}$. ES cells were suspended in neutralized collagen solution to make up cell-matrix mixtures with a final cell density of $1 \times 10^{5}$ cells $/ \mathrm{mL}$ ( 250 cells $/ 2.5 \mu \mathrm{L}$ droplet). Liquid droplets were dispensed onto a nonadhesive surface in a $90-\mathrm{mm}-$ diameter Petri dish (Sterilin, London, United Kingdom) covered with UV-irradiated parafilm and incubated at $37^{\circ} \mathrm{C}$ with $5 \% \mathrm{CO}_{2}$ for $45 \mathrm{~min}$ to induce reconstitution of collagen fiber meshwork as previously described. ${ }^{25}$ Gelated mES cellcollagen microspheres were gently flushed with ES growth medium from the parafilm into the Petri dish and maintained free-floating in suspensions for various periods of time as specified subsequently.

\section{Characterization of the mES cell-encapsulated collagen microspheres}

The temporal morphological change of the mES cellencapsulated collagen microspheres was recorded under a phase contrast microscope up to 14 days. The diameters of both the microspheres and the ES cell aggregates within the microspheres were measured using an eye-piece micrometer. Approximately $10-15 \%$ of the microsphere populations (80/dish) were randomly selected and measured. Moreover, the temporal change of the diameter of 10 randomly selected microspheres per group per time point was also measured during chondrogenic differentiation.

\section{Cell viability and growth kinetics}

On days 3, 7, 10, and 14 postencapsulation, mES cellencapsulated collagen microspheres were incubated with $2 \mu \mathrm{M}$ calcein AM and $4 \mu \mathrm{M}$ ethidium homodimer- 1 in LIVE/ DEAD Viability/Cytotoxicity kit (Molecular Probes, Eugene, OR) for $1 \mathrm{~h}$ for simultaneous staining of live and dead cells. Stained microspheres were fixed in $4 \%$ paraformaldehyde (PFA) for $1 \mathrm{~h}$ and examined using a UV-inverted microscope (Leica DM IRB, Wetzlar, Germany) for fluorescent images. The microspheres were examined using a laser-scanning confocal microscope (Bio-Rad; Radiance 2100, Hercules, CA). In a separate experiment, 100 microspheres per 90mm-diameter Petri dish in duplicates were cultured for 3 , 7, 10, and 14 days. Microspheres were digested enzymatically by collagenase from Clostridium histolyticum (Sigma) at 
100 units/mL for $45-60 \mathrm{~min}$. mES cell aggregates were released from the collagen microspheres and then treated with $0.05 \%$ trypsin $/ 25 \mathrm{mmol}$ EDTA (Gibco) to give a single-cell suspension, which was rinsed with medium before trypan blue staining for cell count and viability.

\section{Immunofluorescent staining of markers for undifferentiated mES cells}

Single-mES suspensions were retrieved from collagen microspheres at different time points postencapsulation and plated on $0.1 \%$ gelatin-coated coverslip overnight. The live mES cells were stained by calcein AM for $1 \mathrm{~h}$ at $37^{\circ} \mathrm{C}$ and then fixed in $4 \%$ PFA at room temperature for $20 \mathrm{~min}$. The fixed mES cells were washed for three times in PBS before immunofluorescent staining. In brief, mES cells were incubated with primary antibodies against undifferentiated ES cell markers, including Oct3/4 (rat monoclonal, $10 \mu \mathrm{g} / \mathrm{mL}$; R\&D Systems, Minneapolis, MN), SSEA-1 (mouse monoclonal, $1 \mu \mathrm{g} / \mathrm{mL}$; R\&D Systems), and Nanog (rabbit polyclonal, $0.5 \mu \mathrm{g} / \mathrm{mL}$; Abcam, Cambridge, United Kingdom) in PBS supplemented with $2 \%$ bovine serum albumin (BSA) overnight at $4{ }^{\circ} \mathrm{C}$. After thorough rinsing, cells were incubated with secondary antibodies, goat anti-rat IgG, goat anti-mouse IgM, and goat antirabbit conjugated with Alexa 546 (1:500 in PBS; Molecular Probes), for primary antibodies against Oct3/4, SSEA-1, and Nanog, respectively, for $1 \mathrm{~h}$ at room temperature. The mES cells were then rinsed thoroughly and mounted on glass slides with fluorescent mounting medium (DakoCytomation, Glostrup, Denmark). mES cells at different time points postencapsulation were imaged under a UV-inverted microscope (Leica DM IRB; excitation at 546). Five views were captured, and about 4001000 cells were counted in each slide. The live cells were in green, while the undifferentiated mES cells were in red.

\section{Flow cytometry analysis for platelet derived growth} factor receptor alpha (PDGFR $\alpha$ )-positive MPCs

$\mathrm{mES}$ cells encapsulated in 0.5 and $2.0 \mathrm{mg} / \mathrm{mL}$ collagen microspheres were cultured for 3, 7, 10, and 14 days in ES cell growth medium with LIF. Single-mES cell suspensions were retrieved from collagen microspheres after collagenase digestion followed by trypsin treatment and cell strainer filtering $(70 \mu \mathrm{m}$ nylon mesh; BD Falcon, Franklin Lake, NJ) for cell counting. About $1 \times 10^{6}$ cells were resuspended in $100 \mu \mathrm{L}$ PBS. $\mathrm{NIH} / 3 \mathrm{~T} 3$ fibroblasts were used as positive controls as they are known to express PDGFR $\alpha$ (ATCC, Manassas, VA). Cells were incubated at room temperature for an hour to allow the recovery of cell surface protein expression after trypsinization. Cells were blocked by $2 \%$ BSA in PBS for 30 min before direct staining of antibodies. To each sample, $20 \mu \mathrm{L}$ of PDGFR $\alpha$ PE-conjugated IgG antibody (Santa Cruz Biotechnology, CA) was added. Isotype controls (normal rabbit PE-conjugated IgG antibody [Santa Cruz Biotechnology]) were performed at each time point. After staining at $4{ }^{\circ} \mathrm{C}$ for $30 \mathrm{~min}, 1000 \mu \mathrm{L}$ PBS was added to each tube to wash off the excess antibodies. After centrifugation at $2000 \mathrm{rpm}$ for $5 \mathrm{~min}$, the supernatant was removed, and the cell pellets were fixed by $1 \%$ PFA for $20 \mathrm{~min}$ before resuspending in $300 \mu \mathrm{L}$ PBS at a cell density not less than $4 \times 10^{5}$ cells $/ \mathrm{mL}$ for FACS analysis. FACSAria Flow Cytometer (BD Biosciences, Bedford, MA) was used for the analysis.

\section{Induction of chondrogenic differentiation}

mES cell-encapsulated collagen microspheres were exposed to chondrogenic differentiation induction signal by cultivating in a chondrogenic differentiation medium, that is, DMEM high glucose (Gibco) supplemented with $10 \mathrm{ng} / \mathrm{mL}$ recombinant human transforming growth factor beta 3 (Peprotech, Rocky Hill, NJ), 100 nM dexamethasone (Sigma), $6 \mathrm{mg} / \mathrm{mL}$ insulin (Merck, Darmstadt, Germany), $100 \mathrm{mM} 2-$ phospho-L-ascorbate (Fluka, St. Louis, MO), $1 \mathrm{mM}$ sodium pyruvate (Gibco), $6 \mathrm{mg} / \mathrm{mL}$ transferrin (Sigma), $0.35 \mathrm{mM} \mathrm{L-}$ prolin (Merck), and $1.25 \mathrm{mg} / \mathrm{mL}$ BSA (Sigma). The microspheres were cultured in ES cell growth medium for 3, 7, 10, and 14 days before induction of chondrogenic differentiation for 21 days.

\section{Histology, histochemistry, and immunohistochemistry of $\mathrm{mES}$ cell-encapsulated microspheres}

Both undifferentiated and differentiated mES cell-collagen microspheres were fixed in $4 \%$ PFA at room temperature for $1 \mathrm{~h}$ and transferred to a series of ethanol with an increasing concentration for dehydration before processing for paraffin sections of $4 \mu \mathrm{m}$ thickness. Routine hematoxylin and eosin (Sigma) staining was conducted to reveal the cell morphology in the microspheres. To evaluate the presence of glycosaminoglycans (GAGs), sections were stained using 1\% Alcian blue 8 GX (Sigma) in 3\% acetic acid ( $\mathrm{pH} 2.5$ ) for $30 \mathrm{~min}$ and counterstained by nuclear fast red. To evaluate the presence of cartilage-specific extracellular matrix type II collagen, a primary antibody (Rabbit polyclonal, $1.25 \mu \mathrm{g} / \mathrm{mL}$; Chemicon) was used. To evaluate the presence of cellular marker of chondrogenic lineages, Sox-9, a primary antibody (Rabbit polyclonal, $2 \mu \mathrm{g} / \mathrm{mL}$; Santa Cruz Biotechnology), was used. Anti-rabbit secondary antibody was used in immunohistochemistry, followed by ABC staining, diaminobenzidine labeling, and counterstaining using hematoxylin.

\section{Quantitative analysis for GAGs}

1,9-Dimethylmethylene blue (DMMB) assay was used to determine the GAG content in mES cell-encapsulated microspheres. ${ }^{54,55}$ Microspheres in triplicates were digested by $300 \mu \mathrm{g} / \mathrm{mL}$ papain $(100 \mu \mathrm{L})$ in $50 \mathrm{mM}$ phosphate buffer $(\mathrm{pH}$ 6.5) containing $5 \mathrm{mM}$ cysteine and $5 \mathrm{mM}$ EDTA at $60^{\circ} \mathrm{C}$ for $16-$ $18 \mathrm{~h}$. The sample solutions were mixed with DMMB reagent at a volume ratio of 1:10 for $30 \mathrm{~min}$. The mixtures were then centrifuged, and the supernatant was discarded. Finally, GAG precipitates were dissolved in $0.2 \mathrm{~mL}$ dissociation solution and added to a 96-well plate for absorbance reading at $656 \mathrm{~nm}$ using a microplate reader (Safire ${ }^{2}$ тм; Tecan Männedorf, Switzerland). GAG concentration was calculated by calibrating against a standard curve of shark chondroitin-6sulfate (Sigma) normalized to the DNA content using a fluorometric assay with Hoechst $33258 .^{56}$ The DNA content was determined against a standard curve of calf thymus DNA (Sigma). Both the standard curves of GAG and the DNA were constructed using duplicates.

\section{Statistical analysis}

Data are presented as means with standard deviations or $95 \%$ confidence intervals. The normality assumption was verified before conducting parametric tests. Two-way ANOVA 


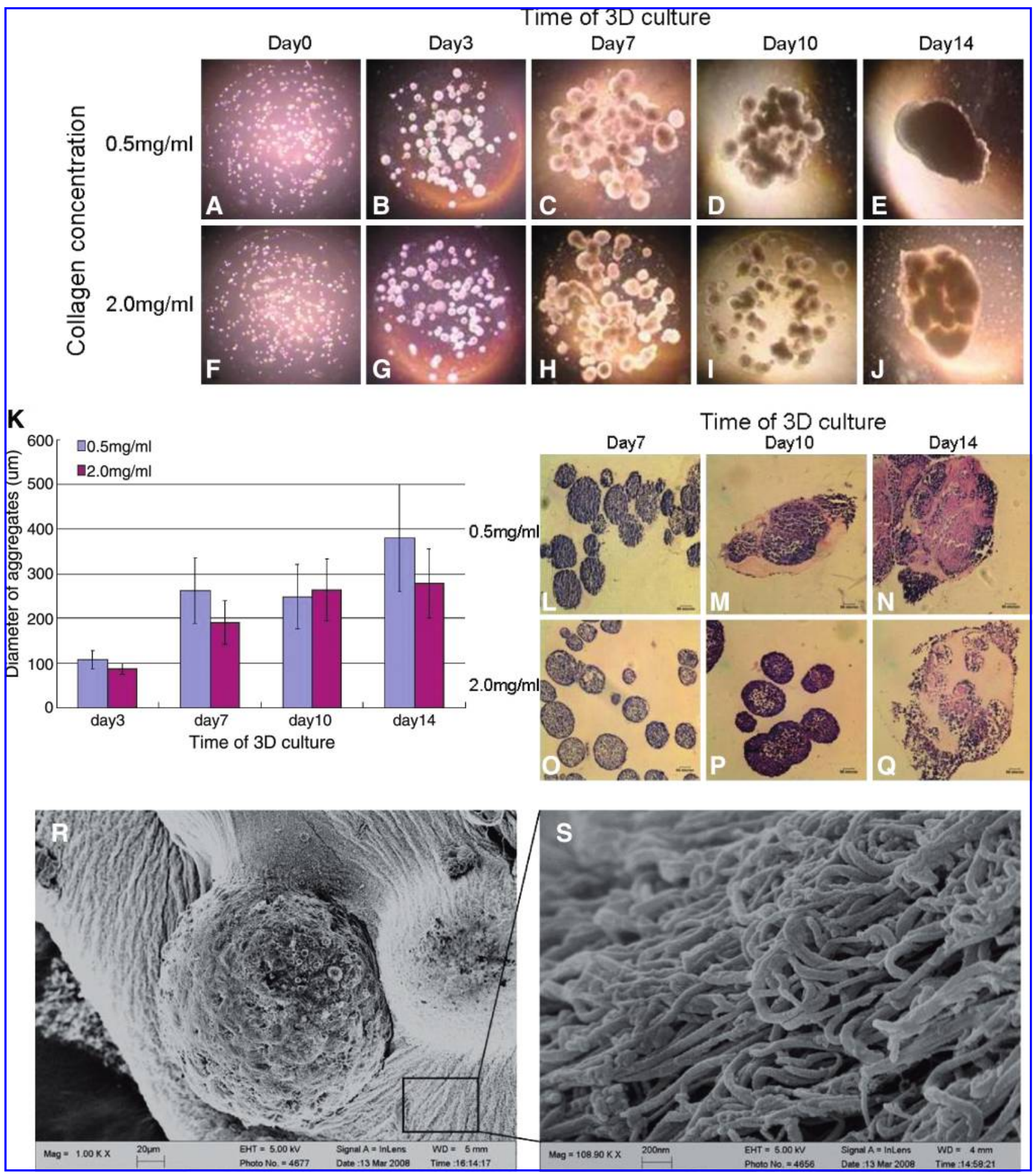

FIG. 1. Morphological and microstructural characterization of mouse embryonic stem (mES) cell-encapsulated collagen microspheres. Upper panel: phase contrast images of mES cell-collagen microspheres with $0.5 \mathrm{mg} / \mathrm{mL}$ collagen $(\mathbf{A}-\mathbf{E})$ and $2.0 \mathrm{mg} / \mathrm{mL}$ collagen $(\mathbf{F}-\mathbf{J})$ in $3 \mathrm{D}$ culture on day $0(\mathbf{A}, \mathbf{F})$, day $3(\mathbf{B}, \mathbf{G})$, day $7(\mathbf{C}, \mathbf{H})$, day $10(\mathbf{D}, \mathbf{I})$, and day $14(\mathbf{E}, \mathbf{J})$ (magnification, $4 \times$ ). Middle panel: (left) change of the mES cell-aggregate size (diameter) within $0.5 \mathrm{and} 2.0 \mathrm{mg} / \mathrm{mL}$ collagen microspheres after postencapsulated for 3, 7, 10, and 14 days (K). Data are presented as mean \pm standard deviation for $n=4$. (Right) H\&E staining in cross-sectional views of ES cell aggregates in microspheres with $0.5 \mathrm{mg} / \mathrm{mL}$ collagen (L-N) and $2.0 \mathrm{mg} / \mathrm{mL}$ collagen $(\mathbf{O}-\mathbf{Q})$ on day $7(\mathbf{L}, \mathbf{O})$, day $10(\mathbf{M}, \mathbf{P})$, and day $14(\mathbf{N}, \mathbf{Q})$ (magnification, $20 \times)$. Scale bars: $50 \mu \mathrm{m}$. Lower panel: scanning electron microscopic image of mES cell aggregates in collagen microspheres (R) and meshwork of randomly distributed collagen nanofibers (S). Color images available online at www.liebertonline.com/ten. 
with appropriate post hoc tests was used to compare the differences in cell number, cell viability, aggregate size, and expressions of markers for undifferentiated mES cells, and the extent of contraction upon differentiation. SPSS 16.0 was used to execute the analyses, and the significance level was set at 0.05 .

\section{Results}

\section{Morphological and microstructural characterization of ES cell-encapsulated collagen microspheres}

Upon encapsulation, mES cells were randomly distributed in the transparent collagen microspheres and proliferated to form tiny aggregates within the collagen microspheres in the following 2 days (Fig. 1). The aggregate size increased over time (Fig. 1A-J). Two-way ANOVA with Dunnett T3 post hoc test showed that there was a significant difference in aggregate size in all groups $(p<0.001)$ (Fig. $1 \mathrm{~K})$, where the difference was due to both the culture period $(p<0.001)$ and the concentration of collagen $(p<0.05)$. Significant differences were found in all groups $(p<0.05)$ except the pair between days 7 and $10(p=0.522)$. Figure $1 \mathrm{~L}-\mathrm{Q}$ shows the $\mathrm{H} \& \mathrm{E}$ staining of mES cell aggregates in collagen microspheres over time. On day 3, the aggregates were too small for paraffin sectioning and were not available for staining. On days 7 and 10, homogenous populations of mES cells were found evenly distributed throughout the cell aggregates (Fig. 1L, M, O, P). On day 14, some aggregates fused together to give larger aggregates (Fig. 1N, Q), which were still largely homogenous (Fig. 1N), and more cells had been found in microspheres with $0.5 \mathrm{mg} / \mathrm{mL}$ collagen. Microstructural analysis of the ES cellcollagen microspheres showed that $\mathrm{mES}$ cell aggregates were

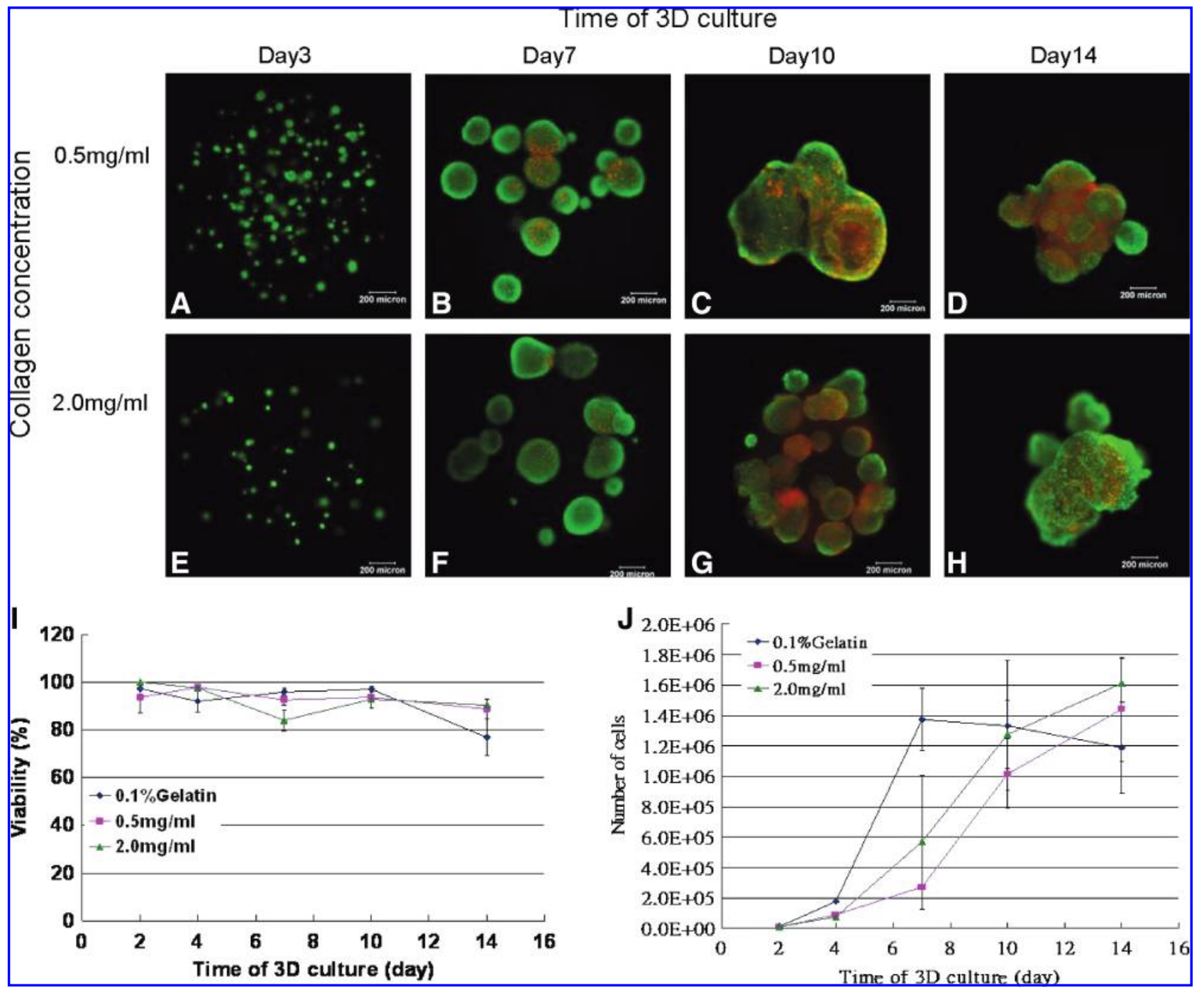

FIG. 2. Viability and growth kinetics of mES cells in collagen microspheres. Upper panel: LIVE/DEAD staining of mES cells in $0.5 \mathrm{mg} / \mathrm{mL}(\mathbf{A}-\mathbf{D})$ and $2.0 \mathrm{mg} / \mathrm{mL}$ collagen $(\mathbf{E}-\mathbf{H})$ on day $3(\mathbf{A}, \mathbf{E})$, day $7(\mathbf{B}, \mathbf{F})$, day $10(\mathbf{C}, \mathbf{G})$, and day $14(\mathbf{D}, \mathbf{H})$ (magnification, $5 \times$ ). Scale bars: $200 \mu \mathrm{m}$. Green (calcein AM), live cells; red (ethidium homodimer-1), dead cells. Lower panel: Viability (I) and growth kinetics (J) of mES cells under different culture conditions, including traditional 2D culture in $0.1 \%$ gelatin-coated plate, and 3D culture in microspheres with $0.5 \mathrm{mg} / \mathrm{mL}$ and $2.0 \mathrm{mg} / \mathrm{mL}$ collagen microspheres. Data are presented as means \pm standard deviations for $n=4$. Color images available online at www.liebertonline.com/ten. 
embedded in a meshwork of randomly distributed collagen nanofibers (Fig. 1R, S).

\section{Viability and growth kinetics of mES cells in collagen microspheres}

Figure 2A-H shows the simultaneous staining of live and dead cells of mES cells in collagen microspheres. Almost all cells were alive in the first 7 days of 3D culture, while some dead cells were observed since day 10. Quantitative analysis showed that cell viability was close to $100 \%$ in the first week and slightly reduced in later time points particularly in microspheres with a higher $(2.0 \mathrm{mg} / \mathrm{mL})$ collagen concentration (Fig. 2I). Two-way ANOVA with Dunnett T3 post hoc test showed that there was a significant difference in viability in all groups $(p<0.001)$, and the difference was due to the time factor $(p<0.001)$, not the culture condition $(p=0.601)$. Viability on day 14 was significantly different from that on days 2 and $4(p<0.05)$ but not on other time points $(p>0.05)$. The growth curves of mES cells in traditional gelatin-coated culture plate, and in 3D collagen microspheres with 0.5 and $2.0 \mathrm{mg} / \mathrm{mL}$ collagen are shown in Figure 2J. mES cells in collagen microspheres proliferated at a much slower rate than those in a traditional gelatin-coated culture dish with a longer lag phase and a later log phase. Nevertheless, cell numbers of collagen microspheres reached the same level as that of the gelatin-coated culture dish at later time points on days 10 and 14. Two-way ANOVA with Dunnett T3 post hoc test showed that there was a significant difference between the early (days 2 and 4) and the later time points (days 7, 10, and 14) $(p<0.05)$, where the difference was due to both the culture condition and the time factor $(p<0.05)$.

\section{Undifferentiated status of live mES cells in collagen microspheres}

Colocalization of live cells in green and markers for undifferentiated mES cells in red, namely, Oct3/4, SSEA-1, or Nanog, was demonstrated (Fig. 3). The upper panel of Figure 3 shows the representative superimposed images of the immunofluorescent staining against Oct3/4 at different time points and with different collagen concentrations $(\mathrm{A}-\mathrm{H})$, while images for SSEA-1 and nanog are shown in the middle and the lower panels of Figure 3, respectively. Quantitative analysis of the percentage of cells with double-positive immunofluorescent staining (orange) out of total live cell populations showed the gradual decreasing trend in the proportion of undifferentiated mES cells over time (upper, middle, and lower panels of Fig. 3, picture I). In general, the proportion of undifferentiated mES cells was greater than $80-90 \%$ in the first week in 3D cultures and was decreasing over time until $\sim 70 \%$ for Oct $3 / 4$ and SSEA- 1 and $\sim 50 \%$ for Nanog on day 14. mES cells in microspheres with $2.0 \mathrm{mg} / \mathrm{mL}$ collagen showed a slightly higher percentage in Oct $3 / 4$ than that with $0.5 \mathrm{mg} / \mathrm{mL}$ collagen at all time points although this was not the case in other markers. Statistical analysis on Oct3/4 and SSEA- 1 showed that there was a significant difference between the early (days 3 and 7$)$ and the later time points (days 10 and 14) $(p<0.05)$, where the difference was due to both the culture period and the concentration of collagen $(p<0.001)$. Statistical analysis on Nanog showed that day 14 was significantly different from days 3,7 , and $10(p<0.05)$, while day 10 was significantly different from days 3 and $7(p<0.05)$. The difference was due to culture period $(p<0.001)$, not the concentration of collagen $(p=0.435)$.

\section{Quantitative analysis of proportion of MPCs in collagen microspheres}

Figure 4 shows the percentage of cells expressing PDGFR $\alpha$, which is a potential marker for MPCs, ${ }^{21}$ in collagen microspheres with different collagen concentrations and at different time points postencapsulation. The histogram showed the net percentage of cells expressing PDGFR $\alpha$ after subtracting the percentage of cells stained by isotype control. Two-way ANOVA showed that the time factor significantly affected the percentage of MPCs $(p<0.05)$ while the concentration factor did not $(p=0.585)$. Dunnett T3 post hoc test showed that there was a significant difference between the early (day 3) and the later time points (days 7, 10, and 14) $(p<0.05)$.

\section{Morphological characterization of chondrogenical differentiated cells in collagen microspheres}

H\&E staining showed the morphological changes of cells after induction of chondrogenic differentiation at different time points and in microspheres with different collagen concentrations (Fig. 5). mES cells in microspheres with $0.5 \mathrm{mg} / \mathrm{mL}$ collagen were differentiated into chondrocyte-like cells, which are round cells with lacunae, when mES cells were exposed to chondrogenic differentiation signals at later time points (7, 10, and 14 days postencapsulation) (Fig. 5A-C). When chondrogenic differentiation was initiated at an early time point at day 3 postencapsulation, mES cells could not be differentiated at all and were all dead (data not shown). Upon differentiation induction at 7 days postencapsulation, the cell aggregates started to fuse together to form a huge aggregate and the microsphere encapsulating them contracted. Clusters of chondrocyte-like cells were identified in the microsphere (Fig. 5A). As the time to initiate the chondrogenic differentiation postponed to 10 days postencapsulation, more and larger clusters of chondrocyte-like cells with larger lacunae structures were identified (Fig. 5B). This phenomenon was more obvious when differentiation was initiated at a later time point at 14 days postencapsulation, as characterized by extensively contracted microspheres, more homogenous cartilage-like structures with chondrocyte-like cells sitting around larger lacunae structures throughout the microsphere (Fig. 5C). However, mES cells in microspheres with $2.0 \mathrm{mg} /$ $\mathrm{mL}$ collagen could not be successfully differentiated into chondrocyte-like cells when they were exposed to chondrogenic differentiation signals (Fig. 5D-F). Specifically, when differentiation was initiated at 7 days postencapsulation, $\mathrm{mES}$ cell density was dramatically decreased after 21 days of differentiation (Fig. 5D). Although the cell densities did not alter significantly when differentiation was initiated at later time points at days 10 and 14 postencapsulation, most, if not all, cells were eosinophilic and no chondrocyte-like cells could be identified (Fig. 5E, F). Quantitative analysis on the diameter of collagen microspheres before and after chondrogenic differentiation is shown in Figure 5G-J. Two-way ANOVA with Dunnett T3 post hoc test showed that there was no significant temporal change in diameter of microsphere before chondrogenic differentiation is initiated $(p>0.05)$ (Fig. 5G). 


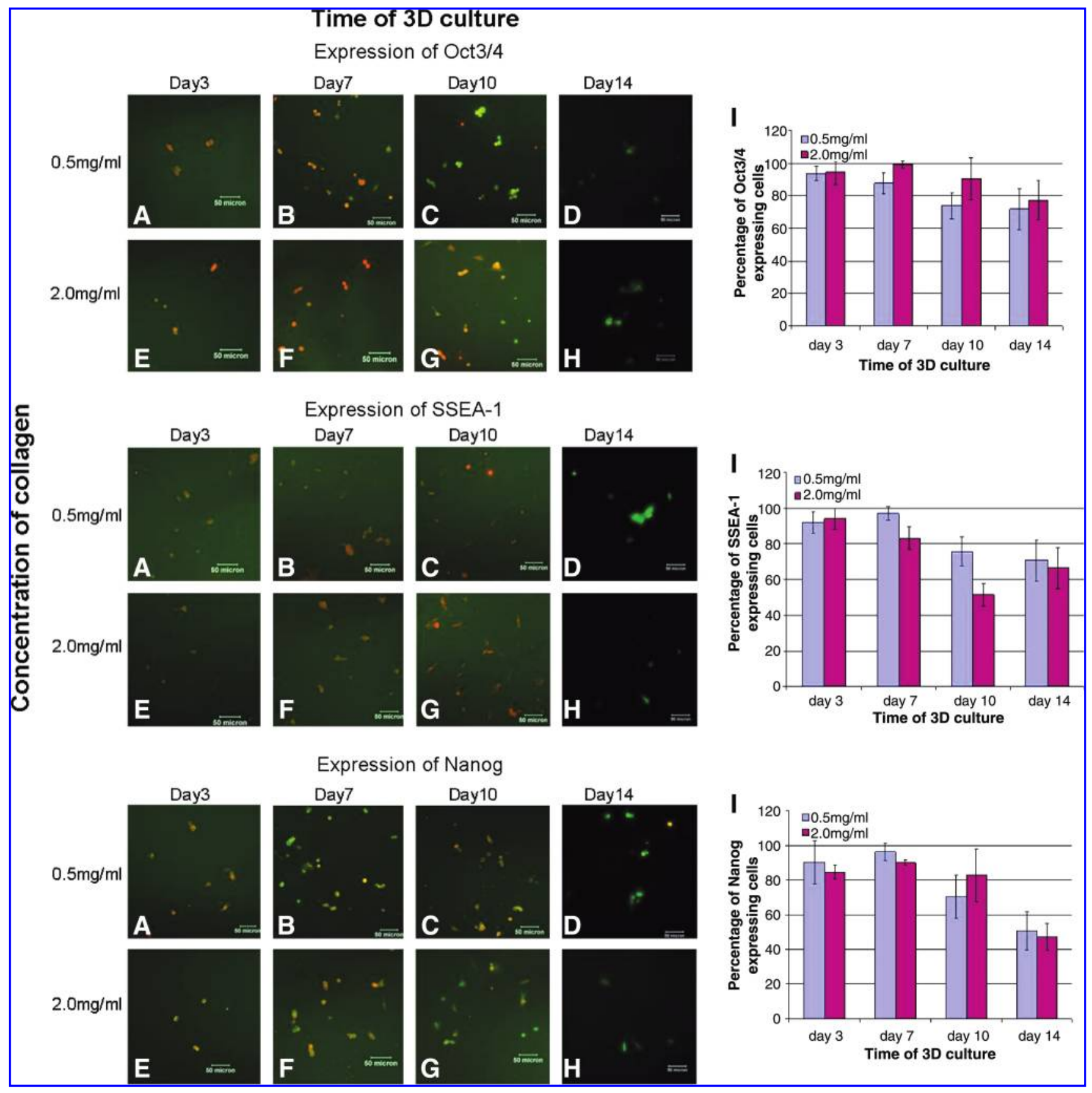

FIG. 3. Expression of markers for live and undifferentiated mES cells in collagen microspheres. Upper panel: double immunofluorescent staining of Oct3 $/ 4$ and calcein AM on mES cells from microspheres with $0.5 \mathrm{mg} / \mathrm{mL}$ collagen (A-D) and $2.0 \mathrm{mg} / \mathrm{mL}$ collagen $(\mathbf{E}-\mathbf{H})$ on day $3(\mathbf{A}, \mathbf{E})$, day $7(\mathbf{B}, \mathbf{F})$, day $10(\mathbf{C}, \mathbf{G})$, and day $14(\mathbf{D}, \mathbf{H})$, and histogram on the percentage of live mES cells expressing Oct3/4 (I). Middle panel: double immunofluorescent staining of SSEA-1 and calcein AM on mES cells from microspheres with $0.5 \mathrm{mg} / \mathrm{mL}$ collagen $(\mathbf{A}-\mathbf{D})$ and $2.0 \mathrm{mg} / \mathrm{mL}$ collagen $(\mathbf{E}-\mathbf{H})$ on day $3(\mathbf{A}, \mathbf{E})$, day 7 (B, F), day 10 $(\mathbf{C}, \mathbf{G})$, and day $14(\mathbf{D}, \mathbf{H})$, and histogram on the percentage of live mES cells expressing SSEA-1 (I). Lower panel: double immunofluorescent staining of Nanog and calcein AM on mES cells from microspheres with $0.5 \mathrm{mg} / \mathrm{mL}$ collagen (A-D) and $2.0 \mathrm{mg} / \mathrm{mL}$ collagen $(\mathbf{E}-\mathbf{H})$ on day $3(\mathbf{A}, \mathbf{E})$, day $7(\mathbf{B}, \mathbf{F})$, day $10(\mathbf{C}, \mathbf{G})$, and day $14(\mathbf{D}, \mathbf{H})$, and histogram on the percentage of live mES cells expressing Nanog (I). Data are presented as means \pm standard deviations for $n=6$ (magnification, $20 \times$ ). Scale bar: $50 \mu \mathrm{m}$. Red: Oct3/4, SSEA-1, or Nanog, markers for undifferentiated status of mES cells; green: calcein AM, marker for live cells released from collagen microspheres. Color images available online at www.liebertonline.com/ten. 


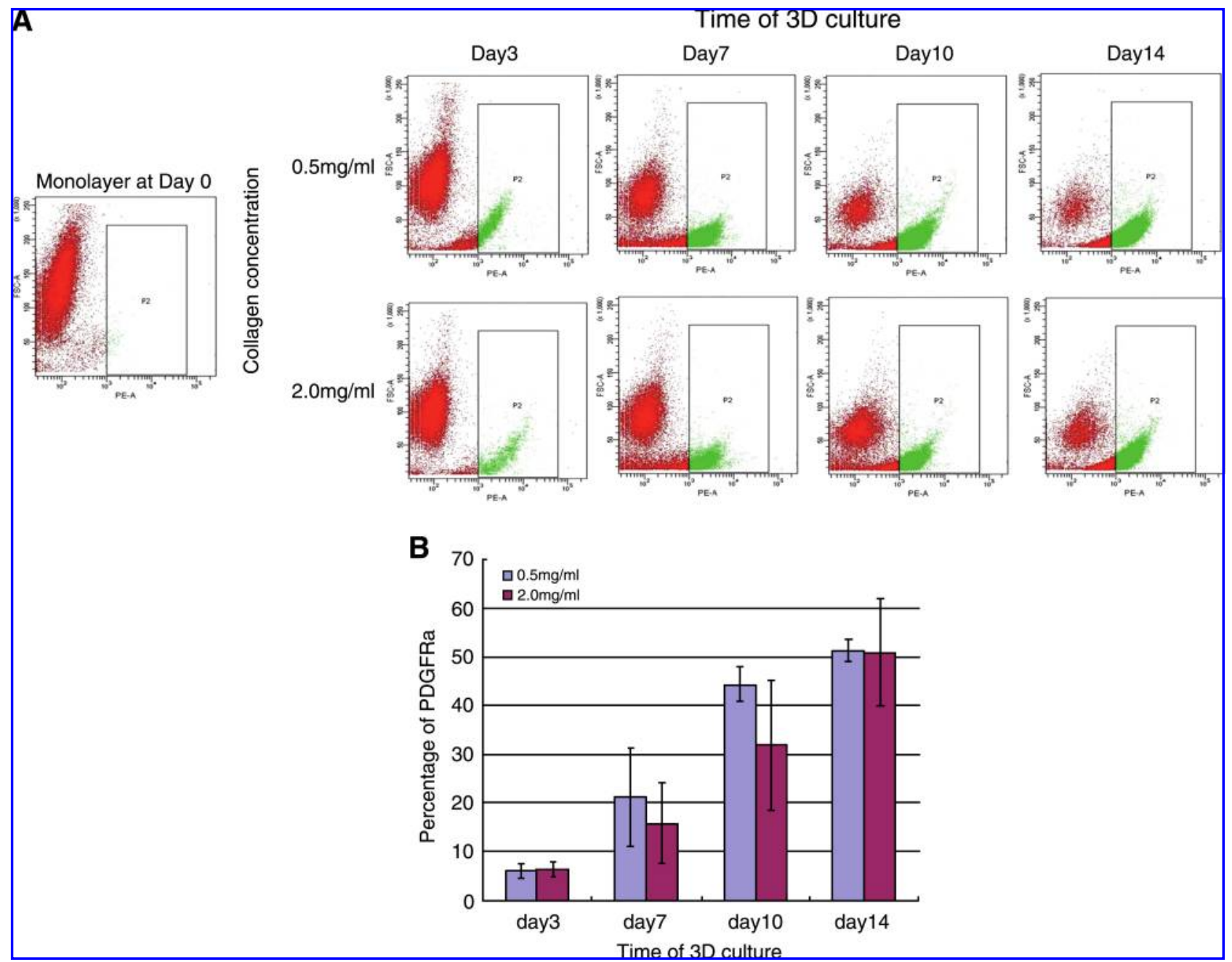

FIG. 4. Flow cytometry analysis of markers for mesenchymal progenitor cells. (A) Profile of cells labeled with anti-PDGFR $\alpha$ antibody conjugated with PE fluorescent signal (orange) in mES cells cultured in monolayers and in microspheres with 0.5 and $2.0 \mathrm{mg} / \mathrm{mL}$ initial collagen concentration on days 3, 7, 10, and 14. (B) Histogram showing the proportion of cells expressing platelet derived growth factor receptor $\alpha$ (PDGFR $\alpha$ ) under different 3D culture conditions after subtracting the isotype control. Data are presented as mean \pm standard deviation for $n=2$. Color images available online at www.liebertonline.com/ten.

However, there was a significant change after the induction of chondrogenic differentiation on day 7 (Fig. 5H), day 10 (Fig. 5I), and day 14 (Fig. 5J), and the difference was due to both the time to induce differentiation and the concentration of collagen $(p<0.001)$.

\section{Histochemical and biochemical characterization of differentiated cells in collagen microspheres}

Alcian blue staining showed GAG-rich regions in the mES cell-encapsulated microspheres after 21 days of chondrogenic induction at 7,10 , and 14 days postencapsulation (Fig. 6A-F). In microspheres with $0.5 \mathrm{mg} / \mathrm{mL}$ collagen, a number of GAG-rich regions could be identified in the microspheres after chondrogenic differentiation when induced at day 7 postencapsulation (Fig. 6A), and the location of these regions matched well with clusters of chondrocyte-like cells in H\&E staining (Fig. 6A). When chondrogenic differentiation was induced at day 10 postencapsulation, Alcian blue staining was more homogenous throughout the microsphere, and there were more GAG-rich regions with more intense staining (Fig. 6B), matching with the presence of chondrocyte-like cell clusters (Fig. 6B). In microspheres differentiated at a later time point on day 14 postencapsulation, extensive staining of GAGs associated with homogenous cartilage-like structures, which were characterized by large chondrocytes in lacunae throughout the microsphere (Fig. 6C). This also matched well with the cartilage-like structures in H\&E staining (Fig. 5C). On the other hand, microspheres with $2.0 \mathrm{mg} / \mathrm{mL}$ collagen showed negative Alcian blue staining in all conditions (Fig. 6D-F). Figure 6G shows the normalized GAG content of the microspheres with and without chondrogenic differentiation medium supplemented at different time points postencapsulation. Induction of differentiation at a later time point did not significantly affect the GAG content, while when the differentiation started at later time points (10 and 14 days postencapsulation), the GAG content significantly increased compared with the control group. Statistically, two-way ANOVA with T3 post hoc test showed that there was a significant difference in GAG/DNA ratio among different groups $(p<0.05)$, and the difference was due to both the time factor and the dif- 


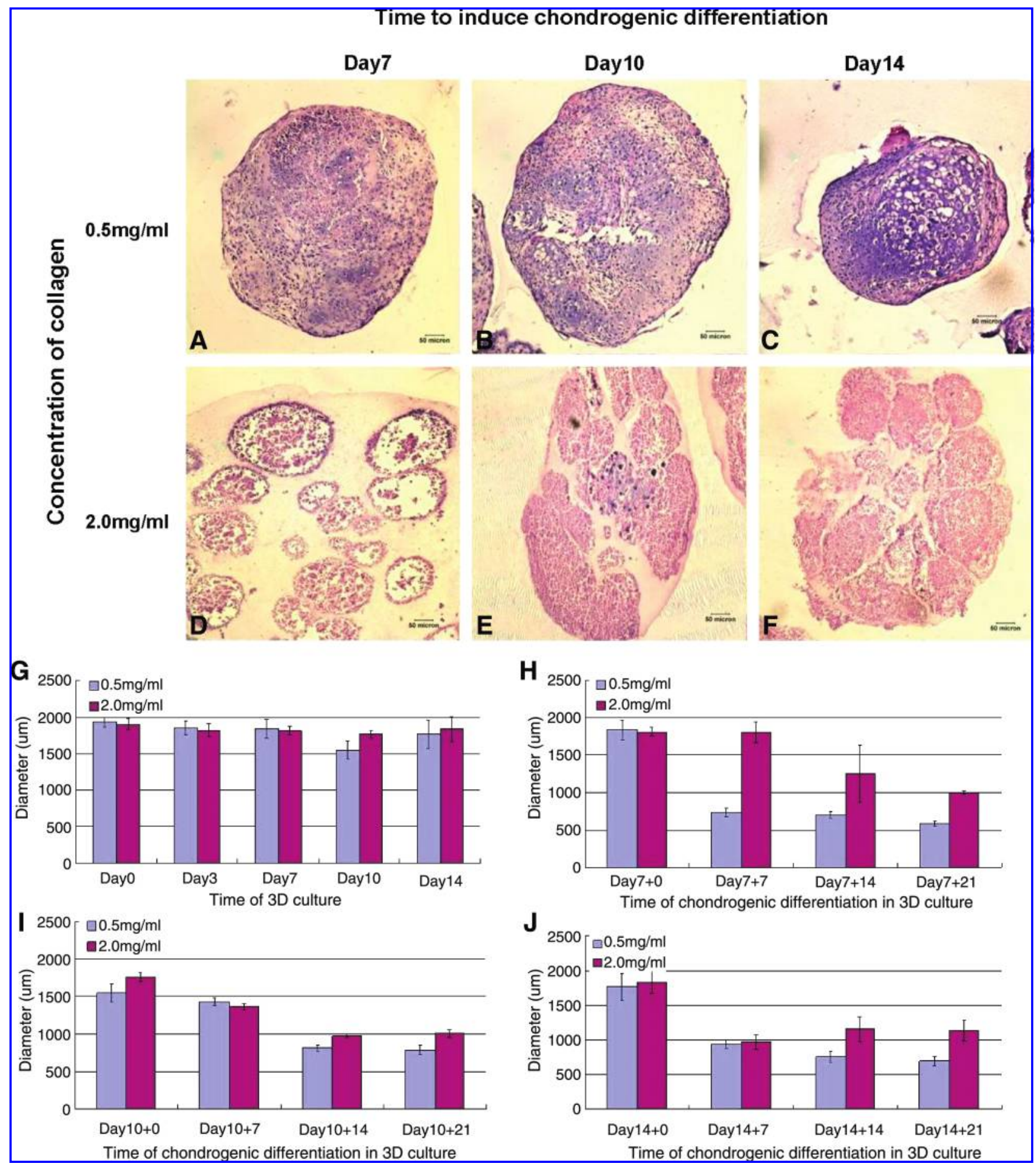

FIG. 5. Morphological characterization of differentiated cells in collagen microspheres. Upper panel: H\&E staining of differentiated cells in collagen microspheres. Cross-sectional views of $0.5 \mathrm{mg} / \mathrm{mL}(\mathbf{A}-\mathbf{C})$ and $2.0 \mathrm{mg} / \mathrm{mL}$ collagen microspheres (D-F) after 21 days of chondrogenic differentiation. Chondrogenic differentiation induction starts on day 7 (A, D), day 10 (B, E), and day 14 (C, F) after encapsulation (magnification, $20 \times$ ). Scale bars: $50 \mu \mathrm{m}$. Lower panel: diameters of 0.5 and $2.0 \mathrm{mg} / \mathrm{mL}$ collagen microspheres $(\mathbf{G})$ before and $(\mathbf{H}-\mathbf{J})$ during chondrogenic differentiation. The induction of chondrogenic differentiation were on day $7(\mathbf{H})$, day $10(\mathbf{I})$, and day 14 (J). Data are presented as mean \pm standard deviation for $n=4$. Color images available online at www.liebertonline.com/ten.

ferentiation group factor $(p<0.05)$. In particular, the GAG/ DNA ratio was significantly increased when the differentiation was initiated at a later time point on day 14 postencapsulation $(p<0.05)$ but not on other time points $(p>0.05)$.
Immunohistochemical characterization of differentiated cells in collagen microspheres

Positive immunoreactivity against another cartilagespecific extracellular matrix marker type II collagen was 


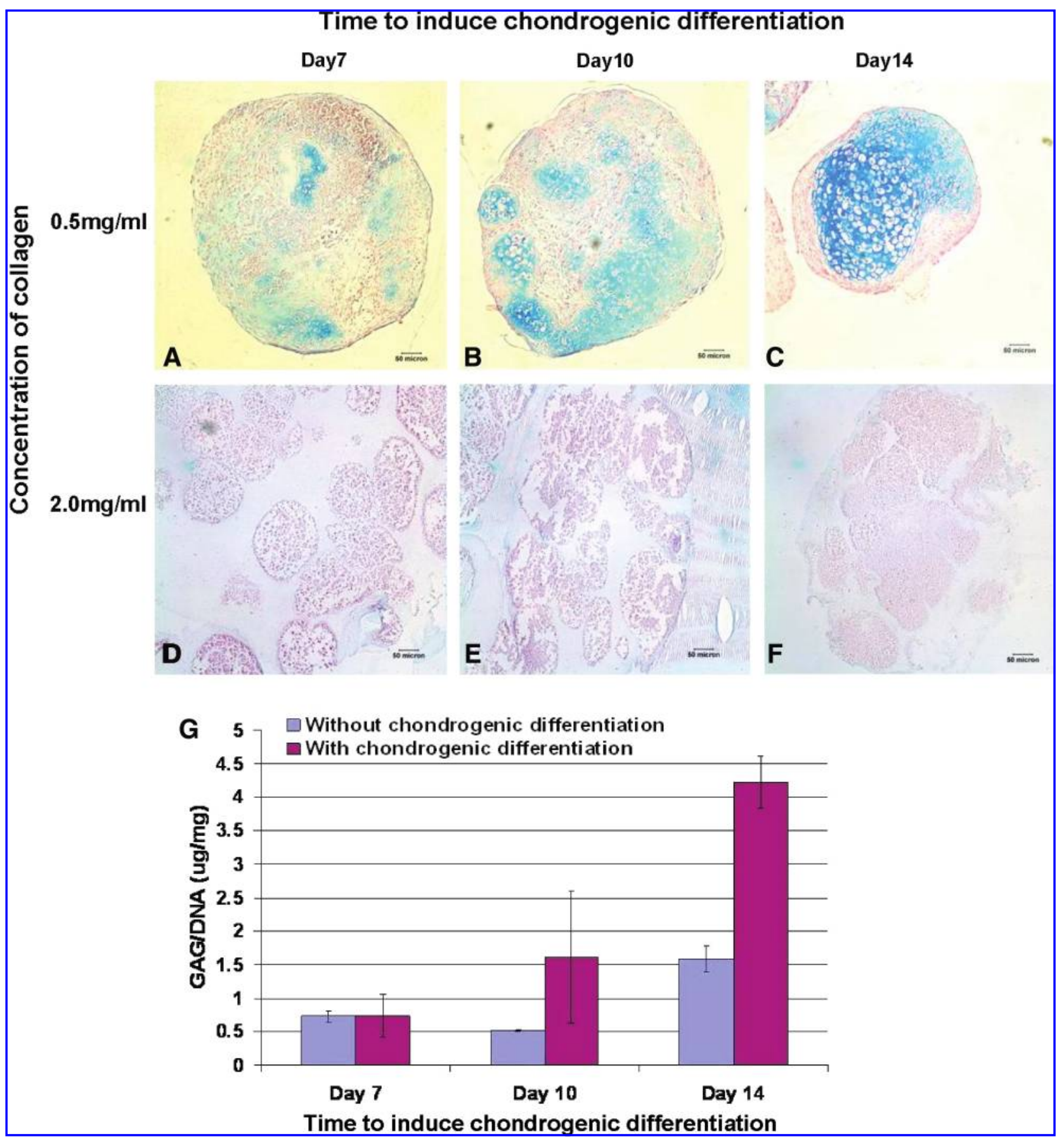

FIG. 6. Histochemical and biochemical characterization of differentiated cells in collagen microspheres. Upper panel: Alcian blue staining of differentiated cells in collagen microspheres. Cross-sectional views of $0.5 \mathrm{mg} / \mathrm{mL}(\mathbf{A}-\mathbf{C})$ and $2.0 \mathrm{mg} / \mathrm{mL}$ collagen microspheres (D-F) after 21 days of chondrogenic differentiation. Chondrogenic differentiation induction starts on day 7 (A, D), day 10 (B, E), and day 14 (C, F) after encapsulation. Blue: Alcian blue staining for proteoglycan (PG)/glycosaminoglycan (GAG)-rich matrix; red: nuclear fast red counterstain (magnification, $20 \times$ ). Scale bars: $50 \mu \mathrm{m}$. Lower panel: GAG/DNA content in $0.5 \mathrm{mg} / \mathrm{mL}$ collagen microspheres was quantified by 1,9-dimethylmethylene blue assay and expressed as GAG/DNA (G). GAG/DNA of microspheres chondrogenically differentiated from day 7 was no significant different before and after 21 days differentiation but increased from days 10 and 14 after 21 days differentiation. Data are presented as mean \pm standard deviation for $n=2$. Color images available online at www.liebertonline.com/ten.

found in both the chondrocyte-like cells and the extracellular matrix in microspheres with $0.5 \mathrm{mg} / \mathrm{mL}$ collagen (Fig. 7A-C). Staining was more homogenous and intense when chondrogenic differentiation was initiated on day 10 postencapsulation (Fig. 7B), and more intensive staining was found when differentiation started on day 14 (Fig. 7C). In microspheres with $2.0 \mathrm{mg} / \mathrm{mL}$ collagen, type II collagen was stained positively only in some cells when differentiation was induced at 7 days postencapsulation (Fig. 7D) but negatively in all other conditions (Fig. 7E, F). Immunolocalization of the nuclear 


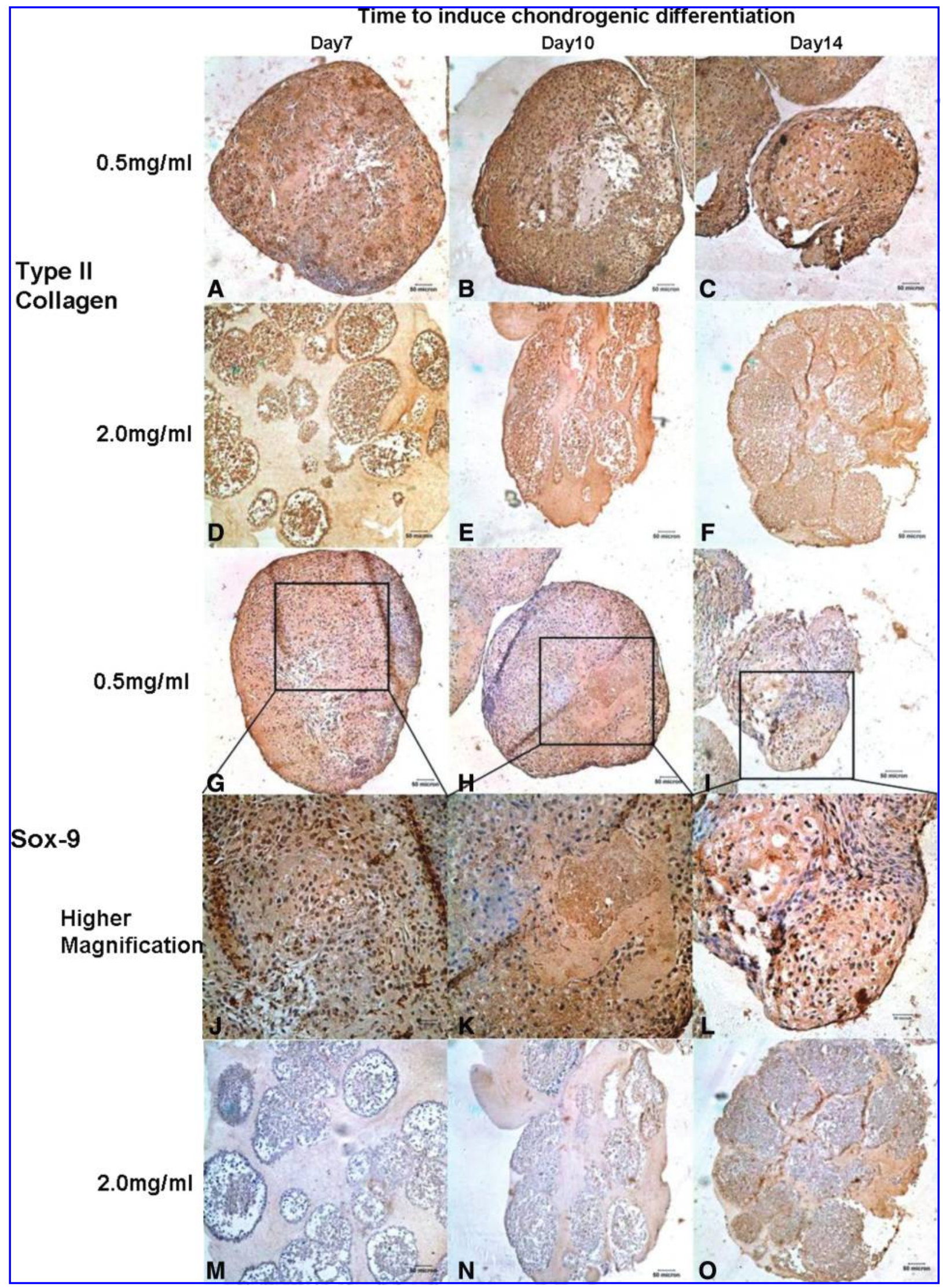

FIG. 7. Immunohistochemical characterization of type II collagen and Sox-9 staining of differentiated cells in collagen microspheres. Upper panel: cross-sectional views of $0.5 \mathrm{mg} / \mathrm{mL}$ (type II collagen, A-C; Sox-9, G-L) and $2.0 \mathrm{mg} / \mathrm{mL}$ collagen microspheres (type II collagen, D-F; Sox-9, M-O) after 21 days of differentiation. Lower panel: cross-sectional views of microspheres on Sox -9 of $0.5 \mathrm{mg} / \mathrm{mL}$ collagen microspheres with a higher magnification $(\mathbf{J}-\mathbf{L})$ after 21 days of chondrogenic differentiation. The positive staining was indicated by diaminobenzidine on matrix with counterstain (magnification, $20 \times$ ). Scale bars: $50 \mu \mathrm{m}$. Color images available online at www.liebertonline.com/ten. 
staining for Sox-9 showed that mES cells were successfully differentiated toward the chondrogenic lineage (Fig. 7G-L). Positive staining was found in chondrocyte-like cells in regions closely associated with the GAG-rich area (Fig. 6A-C) and the type II collagen immunopositive region (Fig. 7A-C) in the extracellular matrix of microspheres with $0.5 \mathrm{mg} / \mathrm{mL}$ collagen. No positive staining for Sox-9 was detected in microspheres with $2.0 \mathrm{mg} / \mathrm{mL}$ (Fig. 7M-O).

\section{Discussion}

\section{An efficient $3 D$ culture system for mES cell}

This study has reported a new approach to culture mES cells in 3D configuration using collagen microencapsulation. In this system, mES cells proliferate inside the collagen microspheres to form cell aggregates. These cell aggregates differ from EBs in both the method of formation and their structures. Specifically, EBs are generated by forced aggregation using hanging drops or centrifugal force in the absence of LIF, while the cell aggregates in the current study are formed by proliferation of single-mES cells encapsulated in the collagenmicrospheres and are therefore similar to those single-cell-derived colonies. Second, cells in EBs spontaneously differentiate to form multiple tissue-like structures and cavities, ${ }^{11,12,57}$ while cell aggregates in the current $3 \mathrm{D}$ culture system are composed of homogenous cell populations without tissue-like structures and cavities. Although the proliferation rate of mES cells in the 3D culture system is initially slower than the traditional 2D cultures (84-fold versus 275-fold of expansion on day 7), the total number of $\mathrm{mES}$ cells expanded reached the same level at later time points (230-fold of expansion at 10 days). This indicates that this 3D culture system is at least as efficient as the traditional 2D system in terms of the magnitude of cell expansion. Moreover, this 3D culture system is able to maintain the undifferentiated status of more than $80 \%$ of $\mathrm{mES}$ cells for at least 1 week. Nevertheless, the percentage of undifferentiated mES cells gradually decreased at later time points, accompanied by an increasing proportion of MPCs, even though LIF was supplemented. This indicates that collagen matrix may play an inductive role in differentiating mES cells toward mesenchymal lineages.

\section{Matrix microenvironment affects the mES cell fate}

mES cells were able to differentiate toward a chondrogenic lineage upon supplementation of induction signals to microspheres with a lower initial collagen concentration $(0.5 \mathrm{mg} / \mathrm{mL})$, as suggested by both cellular and extracellular markers of cartilage formation, including the chondrocytelike morphology, positive immunolocalization of Sox-9 in the nuclei, extensively stained GAG-rich areas and significantly increased GAG content, and high immunoreactivity against type II collagen in the extracellular matrix. On the other hand, mES cells cultured in microspheres with a higher collagen concentration $(2.0 \mathrm{mg} / \mathrm{mL})$ failed to differentiate toward the chondrogenic lineage, as suggested by the absence of chondrocyte-like morphology and Sox-9 expression in all cells and the negative staining for GAG and type II collagen extracellular matrix. The physical information such as the stiffness or the mechanical compliance of the collagen matrix with different concentrations sensed by the encapsulated mES cells may be different. Microspheres with ini- tial collagen concentration of $0.5 \mathrm{mg} / \mathrm{mL}$ are less stiff than that of $2.0 \mathrm{mg} / \mathrm{mL}$, and therefore provide less mechanical constrains to the encapsulated cells. Upon differentiation of mES cells, a lower collagen concentration allows greater extent of cell-induced contraction of the collagen fiber meshwork. This results in higher local cell density and hence greater cell-cell interaction, analogous to what occurs during cellular condensation process preceding chondrogenic differentiation in embryonic skeletal development. ${ }^{58,59}$ The transient $\mathrm{N}$-cadherin signaling, which is exerted by cell-cell contact, has been demonstrated to be highly essential for chondrogenic differentiation of progenitor cells. ${ }^{59}$ On the other hand, collagen at $2.0 \mathrm{mg} / \mathrm{mL}$ provides greater mechanical constrain to the encapsulated cells and reduces the extent of cell-induced contraction of the collagen fiber meshwork upon differentiation. As a result, reduced cell-cell interaction and absence of cellular condensation may lead to the inhibition of chondrogenic differentiation in microspheres with $2 \mathrm{mg} / \mathrm{mL}$ of the initial collagen concentration. Effects of collagen concentration and local cell density on the outcomes of chondrogenic differentiation have also been reported in our previous study using bone marrow MSCs. ${ }^{52}$ Recently, stem cells have been shown to respond to their physical microenvironment, ${ }^{60}$ including matrix elasticity, ${ }^{61,62}$ matrix mechanical compliance, ${ }^{63}$ and mechanical loading signals such as cyclic strain. ${ }^{64}$ A recent report investigates the effects of collagen concentration on EB formation and demonstrated that a higher collagen concentration at $2.4 \mathrm{mg} / \mathrm{mL}$ inhibited cell apoptosis, which is necessary for differentiation and normal cavitation in EBs, and thus the subsequent differentiation toward fibrocartilage. ${ }^{11}$

\section{Time to induce differentiation affects the mES cell fate}

Collagen concentration is a dominating factor, but the time to supplement the induction signals of chondrogenic differentiation to the mES cell-encapsulated microspheres also matters. Early exposure of mES cell aggregates at 3 days postencapsulation did not result in successful chondrogenic differentiation and all cells are dead after 21 days of differentiation (data not shown). This may be due to the lack of cell-cell contact, which is essential for chondrogenic differentiation, ${ }^{59}$ on day 3 postencapsulation. However, when the induction signals were applied to the aggregates at later time points (7 and 14 days postencapsulation), chondrogenic differentiation is successful, and cartilage-like structures were resulted. Moreover, the extent of chondrogenic differentiation seems to positively associate with the timing to induce differentiation, as revealed qualitatively by the homogeneity and the relative proportion of cartilage-like tissue in the microsphere, and quantitatively by the increasing GAG content. Chondrogenic differentiation of mES cells is a multistep process. First, mES cells will commit into MPCs, which then condense into chondroblasts and further differentiate into chondrocytes. ${ }^{16}$ Here we demonstrated that the longer the $\mathrm{mES}$ cells are cultured in the collagen microsphere preceding induction of differentiation, the more the MPCs, which are able to contract the collagen gel, are formed. The increased contraction resulted in a higher local cell density and better cell-cell interaction and therefore a more homogenous cartilage-like structure. Cell-induced collagen contraction has been reported as a functional assay for anchorage-dependent 
cells such as fibroblasts ${ }^{65,66}$ and myofibroblasts. ${ }^{67}$ We also demonstrated that bone marrow MSCs also contract collagen gel in a cell density-dependent manner. ${ }^{51}$ It has been suggested that contraction is a result of close interactions between mesenchymal cells and loose collagen fibrils such as cellular adhesion plaque formation on the collagen fibrils and cellular migration through the collagen fibrils. ${ }^{68,69}$ Nevertheless, no contraction is resulted in anchorage-independent cells, which do not closely interacting with collagen, such as mES cells, neural stem cells, neural crest cells, HEK293 cells, and bone marrow hematopoietic stem cells (data not shown). This explains why no contraction is observed before induction for chondrogenic differentiation, while significant contraction is noted after the induction for chondrogenic differentiation. The increasing proportion of MPCs also explains the greater extent of contraction when chondrogenic differentiation was induced at later time points. Moreover, the current study echoes with a recent report, in which the time line to induce chondrogenic differentiation in EBs has been shown to affect the outcomes in fibrocartilage development, ${ }^{12}$ on the significance of identifying the appropriate window for differentiation induction in stem cells.

\section{Conclusions}

A 3D culture system for mES cells using collagen encapsulation has been established in this study. The reconstituted collagen matrix in the microspheres provides a suitable 3D microenvironment supporting growth of mES cells and maintaining their undifferentiated status for a certain period of time. In this 3D culture system, mES cells can be differentiated directly toward chondrogenic lineages without going through the EB formation stage. Collagen concentration has been demonstrated to be the dominating factor in affecting the outcomes of chondrogenic differentiation as a lower concentration facilitated the chondrogenic differentiation but a higher concentration failed to do so. This demonstrates the importance of extracellular matrix microenvironment or niche in affecting the fate of ES cells. Moreover, a later exposure to the induction signal associates with an increased proportion of MPCs and formation of a more homogenous cartilage tissue. This suggests that the timing to induce chondrogenic differentiation in this 3D culture system is also important in affecting the outcomes of differentiation and indicates that collagen matrix may induce the commitment of undifferentiated mES cells to MPCs.

\section{Acknowledgments}

This work was supported by grants from AOSpine (AOSBRC-07-06); the Innovation and Technology Commission, the Hong Kong Government (GHP/050/06); University Research Committee (10206799); and University's Strategic Research Theme on Development, Growth and Reproduction. The authors thank Prof. Andras Nagy for useful discussion and kind provision of the mES cells (R1), Ms. Alice Lui for technical assistance on the flow cytometry analysis, and the Department of Pediatrics and Adolescent Medicine for providing the flow cytometer for analysis.

\section{Disclosure Statement}

No competing financial interests exist.

\section{References}

1. Doss, M.X., Koehler, C.I., Gissel, C., Hescheler, J., and Sachinidis, A. Embryonic stem cell: a promising tool for cell replacement therapy. J Cell Mol Med 8, 465, 2004.

2. Gardner, R.L., and Brook, F.A. Reflections on the biology of embryonic stem (ES) cells. Int J Dev Biol 41, 235, 1997.

3. Tanaka, T.S., Kunath, T., Kimber, W.L., Jaradat, S.A., Stagg, C.A., Usuda, M., Yokota, T., Niwa, H., Rossant, J., and Ko, M.S. Gene expression profiling of embryo-derived stem cells reveals candidate genes associated with pluripotency and lineage specificity. Genome Res 12, 1921, 2002.

4. Greenlee, A.R., Kronenwetter-Koepel, T.A., Kaiser, S.J., Ellis, T.M., and Liu, K. Combined effects of Matrigel TM and growth factors on maintaining undifferentiated murine embryonic stem cells for embryotoxicity testing. Toxicol In Vitro 18, 543, 2004.

5. Murray, P., and Edgar, D. The regulation of embryonic stem cell differentiation by leukaemia inhibitory factor (LIF). Differentiation 68, 227, 2001.

6. Chambers, I., Colby, D., Robertson, M., Nichols, J., Lee, S., Tweedie, S., and Smith, A. Functional expression cloning of Nanog, a pluripotency sustaining factor in embryonic stem cells. Cell 113, 643, 2003.

7. Ginis, I., Luo, Y., Miura, T., Thies, S., Brandenberger, R., Gerecht-Nir, S., Amit, M., Hoke, A., Carpenter, M.K., Itskovitz-Eldor, J., and Rao, M.S. Differences between human and mouse embryonic stem cells. Dev Bio 269, 360, 2004.

8. Koestenbauer, S., Zech, N.H., Juch, H., Vanderzwalmen, P., Schoonjans, L., and Dohr, G. Embryonic stem cells: similarities and differences between human and murine embryonic stem cells. Am J Reprod Immunol 55, 169, 2006.

9. Mitsui, K., Tokuzawa, Y., Itoh, H., Segawa, K., Murakami, M., Takahashi, K., Maruyama, M., Maeda, M., and Yamanaka, S. The homeoprotein Nanog is required for maintenance of pluripotency in mouse epiblast and ES cells. Cell 113, 631, 2003.

10. Keller, G.M. In vitro differentiation of embryonic stem cells. Curr Opin Cell Biol 7, 862, 1995.

11. Battista, S., Guarnieri, D., Borselli, C., Zeppetelli, S., Borzacchiello, A., Mayol, L., Gerbasio, D., Keene, D.R., Ambrosio, L., and Netti, P.A. The effect of matrix composition of $3 \mathrm{D}$ constructs on embryonic stem cell differentiation. Biomaterials 26, 6194, 2005.

12. Hoben, G.M., Koay, E.J., and Athanasiou, K.A. Fibrochondrogenesis in two embryonic stem cell lines: effects of differentiation timelines. Stem Cells 26, 422, 2008.

13. Lee, J.B., Lee, J.E., Park, J.H., Kim, S.J., Kim, M.K., Roh, S.I., Kim, C.G., and Yoon, H.S. Establishment and maintenance of human embryonic stem cell lines on human feeder cells derived from uterine endometrium under serum-free condition. Biol Reprod 72, 42, 2005.

14. Xu, C., Inokuma, M.S., Denham, J., Golds, K., Kundu, P., Gold, J.D., and Carpenter, M.K. Feeder-free growth of undifferentiated human embryonic stem cells. Nat Biotechnol 19, 971, 2001.

15. Cormier, J.T., zur Nieden, N.I., Rancourt, D.E., and Kallos, M.S. Expansion of undifferentiated murine embryonic stem cells as aggregates in suspension culture bioreactors. Tissue Eng 12, 3233, 2006.

16. Kramer, J., Schlenke, P., and Rohwedel, J. Induction of ES cell-derived cartilage formation. Curr Protoc Cell Biol 23.5.123.5.33, Suppl. 34, 2007.

17. Burridge, P.W., Anderson, D., Priddle, H., Barbadillo Muñoz, M.D., Chamberlain, S., Allegrucci, C., Young, L.E., and Denning, C. Improved human embryonic stem cell embryoid 
body homogeneity and cardiomyocyte differentiation from a novel V-96 plate aggregation system highlights interline variability. Stem Cells 25, 929, 2007.

18. Levenberg, S., Huang, N.F., Lavik, E., Rogers, A.B., Itskovitz-Eldor, J., and Langer, R. Differentiation of human embryonic stem cells on three-dimensional polymer scaffolds. PNAS 100, 12741, 2003.

19. Hatami, L., Valojerdi, M.R., and Mowla, S.J. Effects of oxytocin on cardiomyocyte differentiation from mouse embryonic stem cells. Int J Cardiol 117, 80, 2007.

20. Karbanová, J., and Mokrý, J. Histological and histochemical analysis of embryoid bodies. Acta Histochem 104, 361, 2002.

21. Hegert, C., Kramer, J., Hargus, G., Müller, J., Guan, K., Wobus, A.M., Müller, P.K., and Rohwedel, J. Differentiation plasticity of chondrocytes derived from mouse embryonic stem cells. J Cell Sci 115, 4617, 2002.

22. Kramer, J., Hegert, C., Guan, K., Wobus, A.M., Müller, P.K., and Rohwedel, J. Embryonic stem cell-derived chondrogenic differentiation in vitro: activation by BMP-2 and BMP-4. Mech Dev 92, 193, 2000.

23. Kramer, J., Klinger, M., Kruse, C., Faza, M., Hargus, G., and Rohwedel, J. Ultrastructural analysis of mouse embryonic stem cell-derived chondrocytes. Anat Embryol 210, 175, 2005.

24. Liu, J., Fu, J.D., Siu, C.W., and Li, R.A. Functional sarcoplasmic reticulum for calcium handling of human embryonic stem cell-derived cardiomyocytes: insights for driven maturation. Stem Cells 25, 3038, 2007.

25. Nakayama, N., Duryea, D., Manoukian, R., Chow, G., and Han, C.Y. Macroscopic cartilage formation with embryonic stem-cell-derived mesodermal progenitor cells. J Cell Sci 116, 2015, 2003.

26. Hwang, N.S., Kim, M.S., Sampattavanich, S., Baek, J.H., Zhang, Z., and Elisseeff, J. The effect of three dimensional culture and growth factors on the chondrogenic differentiation of murine embryonic stem cells. Stem Cells 24, 284, 2006

27. Koay, E.J., Hoben, G.M., and Athanasiou, K.A. Tissue engineering with chondrogenically differentiated human embryonic stem cells. Stem Cells 25, 2183, 2007.

28. Tai, G., Polak, J.M., Bishop, A.E., Christodoulou, I., and Buttery, L.D. Differentiation of osteoblasts from murine embryonic stem cells by overexpression of the transcriptional factor osterix. Tissue Eng 10, 1456, 2004.

29. Sui, Y., Clarke, T., and Khillan, J.S. Limb bud progenitor cells induce differentiation of pluripotent embryonic stem cells into chondrogenic lineage. Differentiation 71, 578, 2003.

30. Delise, A.M., Fischer, L., and Tuan, R.S. Cellular interactions and signaling in cartilage development. Osteoarthritis Cartilage 8, 309, 2000.

31. Goldring, M.B., Tsuchimochi, K., and Ijiri, K. The control of chondrogenesis. J Cell Biochem 97, 33, 2006.

32. Tuan, R.S. Cellular signaling in developmental chondrogenesis: N-cadherin, Wnts, and BMP-2. J Bone Joint Surg Am 85A(Suppl 2), 137, 2003.

33. Kawaguchi, J., Mee, P.J., and Smith, A.G. Osteogenic and chondrogenic differentiation of embryonic stem cells in response to specific growth factors. Bone 36, 758, 2005.

34. Tuli, R., Tuli, S., Nandi, S., Huang, X., Manner, P.A., Hozack, W.J., Danielson, K.G., Hall, D.J., and Tuan, R.S. Transforming growth factor-beta-mediated chondrogenesis of human mesenchymal progenitor cells involves $\mathrm{N}$-cadherin and mitogen-activated protein kinase and Wnt signaling crosstalk. I Biol Chem 278, 41227, 2003.
35. Yoon, B.S., and Lyons, K.M. Multiple functions of BMPs in chondrogenesis. J Cell Biochem 93, 93, 2004.

36. zur Nieden, N.I., Kempka, G., Rancourt, D.E., and Ahr, H.J. Induction of chondro-, osteo- and adipogenesis in embryonic stem cells by bone morphogenetic protein-2: effect of cofactors on differentiating lineages. BMC Dev Biol 5, 1, 2005.

37. Delise, A.M., and Tuan, R.S. Analysis of N-cadherin function in limb mesenchymal chondrogenesis in vitro. Dev Dyn 255, 195, 2002.

38. Oberlender, S.A., and Tuan, R.S. Expression and functional involvement of $\mathrm{N}$-cadherin in embryonic limb chondrogenesis. Development 120, 177, 1994.

39. Widelitz, R.B., Jiang, T.X., Murray, B.A., and Chuong, C.M Adhesion molecules in skeletogenesis: II. Neural cell adhesion molecules mediate precartilaginous mesenchymal condensations and enhance chondrogenesis. J Cell Physiol 156, 399, 1993.

40. Fok, E.Y., and Zandstra, P.W. Shear-controlled single-step mouse embryonic stem cell expansion and embryoid bodybased differentiation. Stem Cells 23, 1333, 2005.

41. Nur-E-Kamal, A., Ahmed, I., Kamal, J., Schindler, M., and Meiners, S. Three-dimensional nanofibrillar surfaces promote self-renewal in mouse embryonic stem cells. Stem Cells 24, 426, 2006.

42. Selezneva, I.I., Savintseva, I.V., Vikhlyantseva, E.F., Davydova, G.A., and Gavrilyuk, B.K. Immobilization and long-term culturing of mouse embryonic stem cells in collagen-chitosan gel matrix. Bull Exp Biol Med 142, 119, 2006.

43. Jukes, J.M., Moroni, L., van Blitterswijk, C.A., and de Boer, J. Critical Steps toward a tissue-engineered cartilage implant using embryonic stem cells. Tissue Eng Part A 14, 135, 2008.

44. Liu, H., Collins, S.F., and Suggs, L.J. Three-dimensional culture for expansion and differentiation of mouse embryonic stem cells. Biomaterials 27, 6004, 2006.

45. Chen, S.S., Revoltella, R.P., Papini, S., Michelini, M., Fitzgerald, W., Zimmerberg, J., and Margolis, L. Multilineage differentiation of Rhesus monkey embryonic stem cells in three-dimensional culture systems. Stem Cells 21, 281, 2003.

46. Wang, X., Wang, W., Ma, J., Guo, X., Yu, X., and Ma, X. Proliferation and differentiation of mouse embryonic stem cells in APA microcapsule: a model for studying the interaction between stem cells and their niche. Biotechnol Prog 22, 791, 2006.

47. Ouyang, A., Ng, R., and Yang, S.T. Long-term culturing of undifferentiated embryonic stem cells in conditioned media and three-dimensional fibrous matrices without extracellular matrix coating. Stem Cells 25, 447, 2007.

48. Lee, C.H., Singla, A., and Lee, Y. Biomedical applications of collagen. Int J Pharm 221, 1, 2001.

49. Li, S.T. Tissue-derived biomaterials (collagen). In: Bronzino, J.D., ed. Biomaterials: The Biomedical Engineering Handbook, volume II, 2nd edition. Boca Raton: CRC Press LLC., 2000, p. 42-1-23.

50. Yannas, I.V. Natural materials. In: Ratner, B.D., Hoffman, A.S., Schoen, F.J., and Lemons, J.E., eds. Biomaterials Science: An Introduction to Materials in Medicine, 1st edition. San Diego: Academic Press, 1996, pp. 84-93.

51. Chan, B.P., Hui, T.Y., Yeung, C.W., Li, J., Mo, I., and Chan, G.C. Self-assembled collagen-human mesenchymal stem cell microspheres for regenerative medicine. Biomaterials 28, 4652, 2007.

52. Hui, T.Y., Cheung, K.M.C., Cheung, W.L., Chan, D., and Chan, B.P. In vitro chondrogenic differentiation of human mesenchymal stem cells in collagen microspheres: influence 
of cell seeding density and collagen concentration. Biomaterials 29, 3201, 2008.

53. Nagy, A., Rossant, J., Nagy, R., Abramow-Newerly, W., and Roder, J.C. Derivation of completely cell culture-derived mice from early-passage embryonic stem cells. PNAS 90, 8424, 1993.

54. Barbosa, I., Garcia, S., Barbier-Chassefière, V., Caruelle, J.P., Martelly, I., and Papy-García, D. Improved and simple micro assay for sulfated glycosaminoglycans quantification in biological extracts and its use in skin and muscle tissue studies. Glycobiology 13, 647, 2003.

55. Farndale, R.W., Buttle, D.J., and Barrett, A.J. Improved quantitation and discrimination of sulphated glycosaminoglycans by use of dimethylmethylene blue. Biochim Biophys Acta 883, 173, 1986.

56. Kim, Y.J., Sah, R.L., Doong, J.Y., and Grodzinsky, A.J. Fluorometric assay of DNA in cartilage explants using Hoechst 33258. Anal Biochem 174, 168, 1988.

57. Coucouvanis, E., and Martin, G.R. Signals for death and survival: a two-step mechanism for cavitation in the vertebrate embryo. Cell 83, 279, 1995.

58. Hall, B.K., and Miyake, T. Divide, accumulate, differentiate: cell condensation in skeletal development revisited. Int J Dev Biol 39, 881, 1995.

59. Woodward, W.A., and Tuan, R.S. N-Cadherin expression and signaling in limb mesenchymal chondrogenesis: stimulation by poly-L-lysine. Dev Genet 24, 178, 1999.

60. Discher, D.E., Janmey, P., and Wang, Y.L. Tissue cells feel and respond to the stiffness of their substrate. Science 310, 1139, 2005.

61. Engler, A.J., Sen, S., Sweeney, H.L., and Discher, D.E. Matrix elasticity directs stem cell lineage specification. Cell 126, 677, 2006.

62. Engler, A.J., Sweeney, H.L., Discher, D.E., and Schwarzbauer, J.E. Extracellular matrix elasticity directs stem cell differentiation. J Musculoskelet Neuronal Interact 7, 335, 2007.

63. Li, L., Sharma, N., Chippada, U., Jiang, X., Schloss, R., Yarmush, M.L., and Langrana, N.A. Functional modulation of ES-derived hepatocyte lineage cells via substrate compliance alteration. Ann Biomed Eng 36, 865, 2008.

64. Saha, S., Ji, L., de Pablo, J.J., and Palecek, S.P. Inhibition of human embryonic stem cell differentiation by mechanical strain. J Cell Physiol 206, 126, 2006.

65. Farsi, J.M., and Aubin, J.E. Microfilament rearrangements during fibroblast-induced contraction of three-dimensional hydrated collagen gels. Cell Motil 4, 29, 1984.

66. Huang-Lee, L.L., and Nimni, M.E. Fibroblast contraction of collagen matrices with and without covalently bound hyaluronan. J Biomater Sci Polym Ed 5, 99, 1993.

67. Drobic, V., Cunnington, R.H., Bedosky, K.M., Raizman, J.E., Elimban, V.V., Rattan, S.G., and Dixon, I.M. Differential and combined effects of cardiotrophin-1 and TGF-beta1 on cardiac myofibroblast proliferation and contraction. Am J Physiol Heart Circ Physiol 293, H1053, 2007.

68. McDonald, J.A. Extracellular matrix assembly. Annu Rev Cell Biol 4, 183, 1988.

69. Yamada, K.M., Pankov, R., and Cukierman, E. Dimensions and dynamics in integrin function. Braz J Med Biol Res 36, 959, 2003.

Address correspondence to: Barbara P. Chan, Ph.D.

Medical Engineering Program

Department of Mechanical Engineering

The University of Hong Kong

Room 711, Haking Wong Building, Pokfulam Road Hong Kong Special Administrative Region 852

China

E-mail: bpchan@hkucc.hku.hk

Received: December 6, 2008 Accepted: March 30, 2009

Online Publication Date: May 25, 2009 